\title{
Alkaloids with Nitric Oxide Inhibitory Activities from the Roots of Isatis tinctoria
}

\author{
Dongdong Zhang ${ }^{1,+}$, Yanhong Shi ${ }^{2,+}$, Jingyi Li ${ }^{1}$, Deqing Ruan ${ }^{1}$, Qi Jia ${ }^{1}$, Weiliang Zhu ${ }^{3}$, \\ Kaixian Chen ${ }^{1,3}$, Yiming $\mathrm{Li}^{1, * \mathbb{D}}$ and Rui Wang ${ }^{1, * \mathbb{D}}$ \\ 1 School of Pharmacy, Shanghai University of Traditional Chinese Medicine, Shanghai 201203, China; \\ zhangnatprod@163.com (D.Z.); jobrishua@163.com (J.L.); ruandeqing123@126.com (D.R.); \\ q_jia@126.com (Q.J.); kxchen@mail.shcnc.ac.cn (K.C.) \\ 2 Institute of TCM International Standardization of Shanghai University of Traditional Chinese Medicine, \\ Shanghai 201203, China; shiyhtcm@shutcm.edu.cn \\ 3 Shanghai Institute of Materia Medica, Chinese Academy of Science, Shanghai 201203, China; \\ wlzhu@simm.ac.cn \\ * $\quad$ Correspondence: ymlius@163.com (Y.L.); wr@shutcm.edu.cn (R.W.); Tel.: +86-21-5132-2191 (Y.L.); \\ +86-21-5132-2181 (R.W.); Fax: +86-21-5132-2193 (Y.L. \& R.W.) \\ + These authors contribute equally to this work.
}

Received: 22 October 2019; Accepted: 6 November 2019; Published: 7 November 2019

\begin{abstract}
As our ongoing research project on Ban Lan Gen (Isatis tinctoria roots), a total of 23 alkaloids were obtained. Compounds 1 and 2 contain an unusual $\mathrm{C}-\mathrm{C}$ bond between the $2(\mathrm{H})$-quinolinone moiety and the phenol moiety and between the $2(1 H)$-quinolinone moiety and the $1 H$-indole moiety, respectively. Compound 3 possesses an unusual carbon skeleton and its putative biosynthetic pathway was discussed, and Compound 23 was deduced as a new indole alkaloid glycoside. Compounds 4-7 were identified as four new natural products by extensive spectroscopic experiments. Additionally, the anti-inflammatory activity was assessed based on nitric oxide (NO) production using Lipopolysaccharide-stimulated RAW264.7 macrophages. Compounds $\mathbf{9 , 1 5}$, and 17 showed inhibitory effects with $\mathrm{IC}_{50}$ values of 1.2, 5.0 , and $74.4 \mu \mathrm{M}$.
\end{abstract}

Keywords: Isatis tinctoria roots; alkaloids; structure identification; anti-inflammatory activity

\section{Introduction}

Isatis tinctoria L. (synonym, Isatis indigotica Fort.), named Ban Lan Gen in the Chinese Pharmacopoeia, belongs to the gene Isatis (Brassicaceae family), which is widely distributed and cultivated in the North of the Yangtze River, China [1-4]. Alkaloids were considered as one of the characteristic constituents of this plant, which possess diverse bioactivities such as anti-inflammatory, antiviral, antibacterial, antitumor, and antioxidant activities [5-7]. Up to now, more than 100 alkaloids have been isolated from I. tinctoria, such as indole alkaloids, quinazolone alkaloids, quinoline alkaloids, and so on [1-5]. As our ongoing phytochemical and pharmacological research project on this plant [8-12], four new alkaloids and four new natural products, along with 15 known analogues, were obtained, and their structures and absolute configurations were determined by extensive spectroscopic data analysis, including one-dimensional and two-dimensional-NMR, HRESIMS, and IR, specific rotation data, and electronic circular dichroism (ECD) experiments. The known compounds (4-22, Figure 1) were identified by comparison of their spectroscopic and optical rotation data with those in the reported literature as 4-p-hydroxyphenyl-2(1H)-quinolinone (4) [13], 2-(1H-indol-2-yl)-6-methoxy-4(3H)-quinazolinone (5) [14], 2-(2-hydroxyphenyl)-4(3H)-quinazolinone (6) [15], 2-(but-3-en-1-yl)-4(3H)-quinazolinone (7) [16], 2-(1H-indol-2-yl)-4(3H)-quinolinone (8) [17], tryptanthrin (9) [18], 3-(2,4-dioxo-1,2- dihydroquinazolin-3(4H)-yl)propanoic acid (10) [19], indiforine 
C (11) [3], 4-(2,4-dioxo-1,2-dihydroquinazolin-3(4H)-yl)butanoic acid (12) [20], methyl 4-(2,4-dioxo1,2-dihydroquinazolin-3(4H)-yl)butanoate (13) [21], 3-(2-hydroxyphenyl)- 4(3H)-quinazolinone (14) [22], 3-(2-carboxyphenyl)-4(3H)-quinazolinone (15) [23], 4-methyl-1,2-dihydro-2-oxoquinazoline (16) [24], 2-methyl4(3H)-quinazolinone (17) [25], 4-hydroxy-3-methyl-2(1H)-quinolinone (18) [26], 2-amino-4-quinolinecarboxylic acid (19) [27], 4(1H)-quinolinone (20) [28], 4(1H)-quinolone-3- carboxylic acid (21) [29], and 1,2,3,4-tetrahydro4-hydroxy-quinolinecarboxylic acid (22) [30]. The NO inhibitory activities of the isolates (1-23) were also evaluated against the LPS-stimulated RAW264.7 macrophages. In the present paper, we report the isolation and structure determination, putative biosynthetic pathway, and the NO inhibitory activities of these alkaloids.
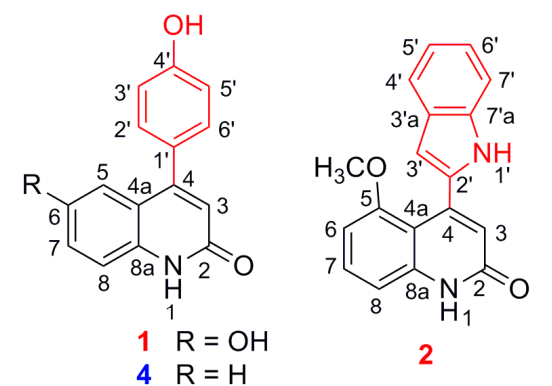

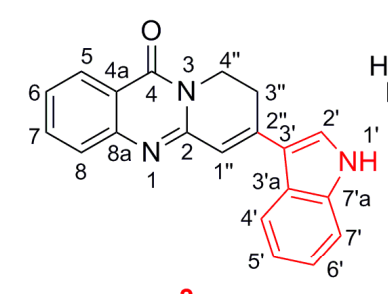

3<smiles>C=CCCc1nc2ccccc2c(=O)[nH]1</smiles>

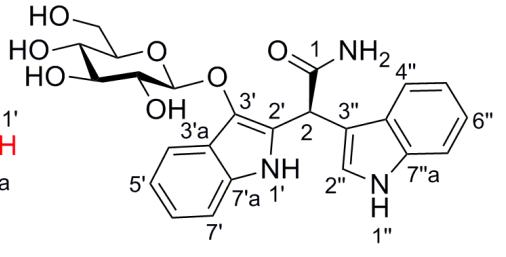

23<smiles>COc1ccc2nc(-c3cc4ccccc4[nH]3)[nH]c(=O)c2c1</smiles>

10<smiles>Cc1nc2ccccc2c(=O)[nH]1</smiles>

17<smiles>O=c1[nH]c(-c2ccccc2O)nc2ccccc12</smiles><smiles>[R]CCCn1c(=O)[nH]c2ccccc2c1=O</smiles><smiles>[R]c1ccccc1-n1cnc2ccccc2c1=O</smiles>

$14 \mathrm{R}=\mathrm{OH}$ $15 \mathrm{R}=\mathrm{COOH}$

$12 \mathrm{R}=\mathrm{COOH}$ $13 \mathrm{R}=\mathrm{COOCH}_{3}$<smiles>Cc1c(O)c2ccccc2[nH]c1=O</smiles>

18<smiles>Nc1cc(C(=O)O)c2ccccc2n1</smiles>

19<smiles>[R]c1c[nH]c2ccccc2c1=O</smiles>

$20 \mathrm{R}=\mathrm{H}$

$21 \mathrm{R}=\mathrm{COOH}$<smiles>O=C1c2ccccc2-n2c1nc1ccccc1c2=O</smiles><smiles>Cc1nc(=O)[nH]c2ccccc12</smiles>

16<smiles>O=C1CC(O)(C(=O)O)c2ccccc2N1</smiles>

22

Figure 1. Structures of Compounds 1-23.

\section{Results and Discussion}

Isatisindigoticanine E (1) was obtained as a yellow amorphous powder. The molecular formula was assigned as $\mathrm{C}_{15} \mathrm{H}_{11} \mathrm{NO}_{3}$ on the basis of the negative ion HRESIMS peak at $m / z 252.0666[\mathrm{M}-\mathrm{H}]^{-}$ (calculated $252.0666[\mathrm{M}-\mathrm{H}]^{-}$), together with its one-dimensional-NMR data (Table 1). The ${ }^{1} \mathrm{H}-\mathrm{NMR}$ spectrum displayed signals of a 1,2,4-trisubstituted benzene ring [31] at $\left[\delta_{\mathrm{H}} 7.20(1 \mathrm{H}, \mathrm{d}, J=2.2 \mathrm{~Hz}, \mathrm{H}-5)\right.$, $6.63(1 \mathrm{H}, \mathrm{dd}, J=8.3,2.2 \mathrm{~Hz}, \mathrm{H}-7)$, and $6.66(1 \mathrm{H}, \mathrm{d}, J=8.3 \mathrm{~Hz}, \mathrm{H}-8)]$, a 1,4 disubstituted benzene ring at $\left[\delta_{\mathrm{H}} 7.57\left(2 \mathrm{H}, \mathrm{d}, J=8.5 \mathrm{~Hz}, \mathrm{H}-2^{\prime}, 6^{\prime}\right)\right.$ and $6.90\left(2 \mathrm{H}, \mathrm{d}, J=8.5 \mathrm{~Hz}, \mathrm{H}-3^{\prime}, 5^{\prime}\right)$ and also showed a trisubstituted double bond [9] at $\delta_{\mathrm{H}} 7.48(1 \mathrm{H}, \mathrm{s}, \mathrm{H}-3)$ and three exchangeable protons at $\delta_{\mathrm{H}} 10.19(1 \mathrm{H}, \mathrm{brs}, \mathrm{NH}-1)$, $10.12(1 \mathrm{H}$, brs, $\mathrm{OH}-6)$, and $8.96\left(1 \mathrm{H}, \mathrm{brs}, \mathrm{OH}-4^{\prime}\right)$. The ${ }^{13} \mathrm{C}-\mathrm{NMR}$ spectrum showed 15 carbon signals, among which $7 \times C$ carbons at $\delta_{C}(169.5,159.6,152.2,135.4,126.1,125.4,122.5)$ and $8 \times \mathrm{CH}$ carbons at $\delta_{C}(136.7,132.1,132.1,116.5,116.1,116.1,110.7,110.1)$ were found based on the DEPT 135 experiment. The two-dimensional-NMR spectroscopic features confirmed the inference above. The proton and protonated carbon resonances in the NMR spectra of $\mathbf{1}$ were unambiguously assigned by the HSQC 
experiments [32,33]. The ${ }^{1} \mathrm{H}-{ }^{1} \mathrm{H}$ COSY correlations (Figure 2) of $\mathrm{H}-2^{\prime}, 6^{\prime} / \mathrm{H}-3^{\prime}, 5^{\prime}$, along with $\mathrm{HMBC}$ correlations (Figure 2) of $\mathrm{H}-2^{\prime} / \mathrm{C}-4^{\prime}$ and $\mathrm{H}-3^{\prime} / \mathrm{C}-1^{\prime}$, indicated a phenol moiety in $\mathbf{1}$ [31]; ${ }^{1} \mathrm{H}-{ }^{1} \mathrm{H}$ COSY correlations of $\mathrm{H}-7 / \mathrm{H}-8$, along with the HMBCs of NH-1/C-2, C-8, and C-8a, H-3/C-2, and C-4, and $\mathrm{H}-5 / \mathrm{C}-4$ and C-7, indicated a 6-hydroxy-2(1H)-quinolinone moiety in 1 [34]; HMBCs of H-3/C-1' and $\mathrm{H}-2^{\prime}, 6^{\prime} / \mathrm{C}-4$ confirmed the 6-hydroxy-2(1H)-quinolinone moiety connected with the phenol moiety via a C-4-C-1' bond. The structure of $\mathbf{1}$ was then determined, as depicted in Figure 1.

Table 1. ${ }^{1} \mathrm{H}-\mathrm{NMR}\left(600 \mathrm{MHz}\right.$ in DMSO- $\left.d_{6}\right)$ and ${ }^{13} \mathrm{C}-\mathrm{NMR}$ data $\left(150 \mathrm{MHz}\right.$ in DMSO- $\left.d_{6}\right)$ of 1-3.

\begin{tabular}{|c|c|c|c|c|c|c|}
\hline \multirow{2}{*}{ No. } & \multicolumn{2}{|l|}{1} & \multicolumn{2}{|l|}{2} & \multicolumn{2}{|l|}{3} \\
\hline & $\delta \mathrm{H}$ & $\delta \mathrm{C}$ & $\delta \mathrm{H}$ & $\delta \mathrm{C}$ & $\delta \mathrm{H}$ & $\delta \mathrm{C}$ \\
\hline 1 & $10.19, \mathrm{~s}$ & & 12.06, brs & & & \\
\hline 2 & & 169.5 & & 168.3 & & 156.8 \\
\hline 3 & $7.48, \mathrm{~s}$ & 136.7 & $8.63, \mathrm{~s}$ & 130.6 & & \\
\hline 4 & & 126.1 & & 118.8 & & 160.5 \\
\hline $4 a$ & & 122.5 & & 116.8 & & 120.3 \\
\hline 5 & $7.20, \mathrm{~d}(2.2)$ & 110.1 & & 155.0 & $8.13, \mathrm{~d}(8.0)$ & 126.3 \\
\hline 6 & & 152.2 & $6.67, \mathrm{~d}(7.5)$ & 102.6 & $7.47, \mathrm{dd}(8.0,7.2)$ & 126.0 \\
\hline 7 & $6.63, \mathrm{dd}(8.3,2.2)$ & 110.7 & 7.15, overlap & 123.9 & $7.82, \mathrm{dd}(8.1,7.2)$ & 134.9 \\
\hline 8 & $6.66, \mathrm{~d}(8.3)$ & 116.5 & $6.85, \mathrm{~d}(7.3)$ & 106.2 & $7.72, \mathrm{~d}(8.1)$ & 126.2 \\
\hline $8 a$ & & 135.4 & & 138.0 & & 148.8 \\
\hline $1^{\prime}$ & & 125.4 & $10.51, \mathrm{~s}$ & & 11.98, brs & \\
\hline $2^{\prime}$ & 7.57, d (8.5) & 132.1 & & 112.5 & $7.84, \mathrm{~d}(2.2)$ & 128.3 \\
\hline $3^{\prime}$ & $6.90, \mathrm{~d}(8.5)$ & 116.1 & $9.45, \mathrm{~s}$ & 133.5 & & 112.5 \\
\hline 3'a & & & & 126.3 & & 127.4 \\
\hline $4^{\prime}$ & & 159.6 & 7.50, d (7.5) & 117.9 & $7.87, \mathrm{~d}(7.5)$ & 118.5 \\
\hline $5^{\prime}$ & $6.90, d(8.5)$ & 116.1 & 7.15 , overlap & 121.1 & $7.22, \mathrm{dd}(8.1,7.5)$ & 120.9 \\
\hline $6^{\prime}$ & $7.57, \mathrm{~d}(8.5)$ & 132.1 & $7.00, \mathrm{dd}(7.5,7.4)$ & 127.0 & $7.25, \mathrm{dd}(8.1,7.5)$ & 123.0 \\
\hline $7^{\prime}$ & & & 7.14, overlap & 109.5 & $7.50, \mathrm{~d}(7.5)$ & 112.6 \\
\hline 7'a & & & & 139.4 & & 136.4 \\
\hline $1^{\prime \prime}$ & & & & & $8.13, \mathrm{~s}$ & 122.6 \\
\hline $2^{\prime \prime}$ & & & & & & 125.6 \\
\hline $3^{\prime \prime}$ & & & & & $3.17,2 \mathrm{H}, \mathrm{m}$ & 26.2 \\
\hline $4 "$ & & & & & $4.25,2 \mathrm{H}, \mathrm{t}(7.0)$ & 44.7 \\
\hline $\mathrm{OMe}$ & & & $4.04, \mathrm{~s}$ & 55.9 & & \\
\hline $6-\mathrm{OH}$ & $10.12, \mathrm{~s}$ & & & & & \\
\hline $4^{\prime}-\mathrm{OH}$ & $8.96, \mathrm{~s}$ & & & & & \\
\hline
\end{tabular}

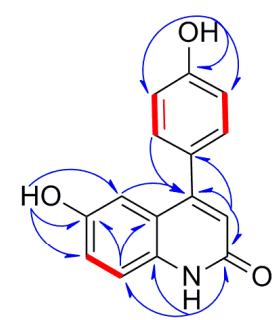

1

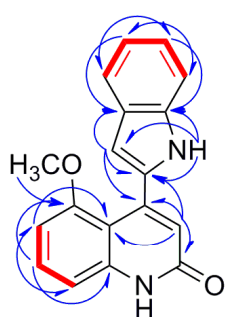

2

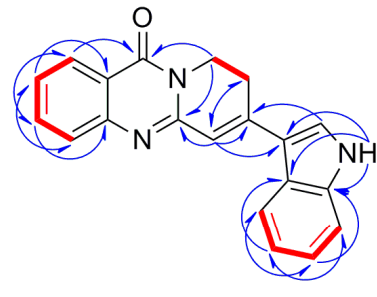

3

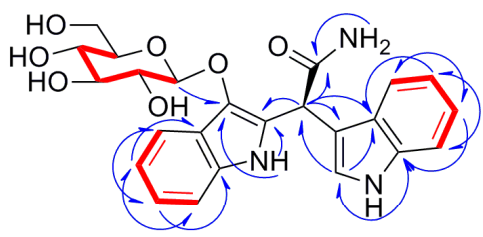

23

- $:{ }^{1} \mathrm{H}-{ }^{1} \mathrm{H} \cos Y \overparen{\mathrm{H}} \mathrm{C}: \mathrm{HMBC}$

Figure 2. Key ${ }^{1} \mathrm{H}-{ }^{1} \mathrm{H}$ COSY and HMBC correlations of Compounds 1-3 and 23.

Isatisindigoticanine $\mathrm{F}(2)$ was obtained as a yellow amorphous powder. The molecular formula was assigned as $\mathrm{C}_{18} \mathrm{H}_{14} \mathrm{~N}_{2} \mathrm{O}_{2}$ by the one-dimensional-NMR data and the HRESIMS positive ion peak at $\mathrm{m} / \mathrm{z} 291.1125[\mathrm{M}+\mathrm{H}]^{+}$(calculated $291.1128[\mathrm{M}+\mathrm{H}]^{+}$). The ${ }^{1} \mathrm{H}-\mathrm{NMR}$ spectrum (Table 1 ) of 2 showed signals of a 1,2,3-trisubstituted benzene ring at $\left[\delta_{\mathrm{H}} 6.67(1 \mathrm{H}, \mathrm{d}, J=7.5 \mathrm{~Hz}, \mathrm{H}-6), 7.15(1 \mathrm{H}\right.$, overlap, H-7) 
and $6.85(1 \mathrm{H}, \mathrm{d}, J=7.3 \mathrm{~Hz}, \mathrm{H}-8)]$, an ortho-disubstituted benzene ring at $\left[\delta_{\mathrm{H}} 7.50(1 \mathrm{H}, \mathrm{d}, J=7.5 \mathrm{~Hz}\right.$, H-4'), $7.15\left(1 \mathrm{H}\right.$, overlap, H-5'), $7.00\left(1 \mathrm{H}, \mathrm{dd}, J=7.5,7.4 \mathrm{~Hz}, \mathrm{H}-6^{\prime}\right)$ and $7.14(1 \mathrm{H}$,overlap, H-7')] [35]; two trisubstituted double bonds at $\delta_{\mathrm{H}} 8.63(1 \mathrm{H}, \mathrm{s}, \mathrm{H}-3)$ and $9.54\left(1 \mathrm{H}, \mathrm{s}, \mathrm{H}-3^{\prime}\right)$, as well as two exchangeable protons at $\delta_{\mathrm{H}} 12.06(1 \mathrm{H}, \mathrm{brs}, \mathrm{NH}-1)$ and $10.51\left(1 \mathrm{H}, \mathrm{brs}, \mathrm{NH}-1^{\prime}\right)$ and a methoxy group at $\delta_{\mathrm{H}} 4.04$ $(3 \mathrm{H}, \mathrm{s}, 5-\mathrm{OMe})$. After analysis of the ${ }^{13} \mathrm{C}-\mathrm{NMR}$, DEPT 135 and HSQC data (Table 1$)$, a $1 H$-indol-2-yl moiety (112.5, C; 133.5, CH; 126.3, C; 117.9, CH; 121.1, CH; 127.0, CH; 109.5, CH; 139.4, C) [8,10] and a 5-methoxy-2(1H)-quinolinone moiety (168.3, C; 130.6, CH; 118.8, C; 116.8, C; 155.0, C; 102.6, CH; 123.9, $\mathrm{CH} ; 106.2, \mathrm{CH} ; 138.0, \mathrm{C} ; 55.9, \mathrm{CH}_{3}$ ) were observed [34]. HMBCs of $\mathrm{H}-3 / \mathrm{C}-2$ ' and $\mathrm{H}-3^{\prime} / \mathrm{C}-4$ indicated the $1 H$-indol-2-yl moiety connected with the 5-methoxy-2(1H)-quinolinone moiety via a C-4-C-2' bond. These inferences were confirmed by detailed analysis of the two-dimensional-NMR data including HSQC, HMBC (Figure 2), and ${ }^{1} \mathrm{H}-{ }^{1} \mathrm{H}$ COSY (Figure 2) experiments. The structure of 2 was thus deduced, as depicted in Figure 1.

Isatisindigoticanine $\mathrm{G}(3)$, a yellow amorphous powder, possessed the molecular formula of $\mathrm{C}_{20} \mathrm{H}_{15} \mathrm{~N}_{3} \mathrm{O}$ based on the positive HRESIMS ion at $m / z 314.1297[\mathrm{M}+\mathrm{H}]^{+}\left(\right.$calculated $314.1288[\mathrm{M}+\mathrm{H}]^{+}$) and one-dimensional-NMR data. The ${ }^{1} \mathrm{H}-\mathrm{NMR}$ spectrum (Table 1) of 3 showed signals of two ortho-disubstituted benzene rings at $\left[\delta_{\mathrm{H}} 8.13(1 \mathrm{H}, \mathrm{d}, J=8.0 \mathrm{~Hz}, \mathrm{H}-5), 7.47(1 \mathrm{H}, \mathrm{dd}, J=8.0,7.2 \mathrm{~Hz}, \mathrm{H}-6)\right.$, $7.82(1 \mathrm{H}, \mathrm{dd}, J=8.1,7.2 \mathrm{~Hz}, \mathrm{H}-7)$ and $7.72(1 \mathrm{H}, \mathrm{d}, J=8.1 \mathrm{~Hz}, \mathrm{H}-8)]$ and $\left[\delta_{\mathrm{H}} 7.87(1 \mathrm{H}, \mathrm{d}, J=7.5 \mathrm{~Hz}\right.$, $\left.\mathrm{H}-4^{\prime}\right), 7.22\left(1 \mathrm{H}, \mathrm{dd}, J=8.1,7.5 \mathrm{~Hz}, \mathrm{H}-5^{\prime}\right), 7.25\left(1 \mathrm{H}, \mathrm{dd}, J=8.1,7.5 \mathrm{~Hz}, \mathrm{H}-6^{\prime}\right)$ and $7.50(1 \mathrm{H}, \mathrm{d}, J=7.5$ $\left.\left.\mathrm{Hz}, \mathrm{H}-7^{\prime}\right)\right]$, two trisubstituted double bonds at $\delta_{\mathrm{H}} 7.84\left(1 \mathrm{H}, \mathrm{d}, J=2.2 \mathrm{~Hz}, \mathrm{H}-2^{\prime}\right)$ and $8.13\left(1 \mathrm{H}, \mathrm{s}, \mathrm{H}-1^{\prime \prime}\right)$, as well as an exchangeable proton at $\delta_{\mathrm{H}} 11.98\left(1 \mathrm{H}, \mathrm{brs}, \mathrm{NH}-1^{\prime}\right)$ [35]. The ${ }^{13} \mathrm{C}-\mathrm{NMR}$ and the DEPT 135 spectra (Table 1 ) displayed $8 \times C$ carbons at $\delta_{C}(160.5,156.8,148.8,136.4,127.4,125.6,120.3,112.5)$, $10 \times \mathrm{CH}$ carbons at $\delta_{\mathrm{C}}(134.9,128.3,126.3,126.2,126.0,123.0,122.6,120.9,118.5,112.6)$, and $2 \times \mathrm{CH}_{2}$ carbons at $\delta_{\mathrm{C}}(44.7,26.2)$. The two-dimensional-NMR spectra (Figure 2) of 3 showed the ${ }^{1} \mathrm{H}-{ }^{1} \mathrm{H}$ COSY correlations of $\mathrm{H}-5 / \mathrm{H}-6 / \mathrm{H}-7 / \mathrm{H}-8, \mathrm{H}-3$ " $/ \mathrm{H}-4$ " and HMBCs from $\mathrm{H}-5 / \mathrm{C}-4$ from $\mathrm{H}-1$ "'/C-2 and C-3" and from $\mathrm{H}-4$ " /C-2 and C-4, which indicated a $8 H$-pyrido[2,1-b]-11(9H)-quinazolinone moiety in 3 [36]; ${ }^{1} \mathrm{H}-{ }^{1} \mathrm{H}$ COSY correlations of $\mathrm{H}-4^{\prime} / \mathrm{H}-5^{\prime} / \mathrm{H}-6^{\prime} / \mathrm{H}-7^{\prime}$ and the HMBCs from NH-1'/C-2', C-3', C-3'a, and C-7'a indicated a $1 H$-indol-3-yl moiety in 3 [10]. HMBCs from NH-1'/C-9 and C-6, and from H-2'/C-2" and $\mathrm{H}-1$ "'/C-3' determined the $8 \mathrm{H}$-pyrido[2,1-b]-11(9H)-quinazolinone moiety connected with the $1 H$-indol-3-yl moiety via a C-2"-C-3' bond. The structure of $\mathbf{3}$ was thus determined, as depicted in Figure 1.

Isatindigoside $\mathrm{D}$ (23) was isolated as a red amorphous powder with $[\alpha]_{D}^{20}+12.1^{\circ}(c 0.19, \mathrm{MeOH})$. Its molecular formula of $\mathrm{C}_{23} \mathrm{H}_{22} \mathrm{~N}_{2} \mathrm{O}_{7}$ (14 IHD) was deduced from the NMR data and the HRESIMS positive ion peak at $m / z 490.1592[\mathrm{M}+\mathrm{Na}]^{+}$, $\left(\right.$calculated $\left.490.1585[\mathrm{M}+\mathrm{Na}]^{+}\right)$. When comparing the one-dimensional (Table 2) and two-dimensional-NMR data (Figure 2) with the reported bisindoloside of isatindigobisindoloside $C$ [35], they showed almost identical NMR spectroscopic features except for the differences around C-2 (downfield of C-2', C-3', and C-3", upfield of C-2"). These differences, along with the optical rotation data $\left([\alpha]_{D}^{20}+12.1, c 0.19\right.$ in $\left.\mathrm{MeOH}\right)$ supported Compound 23, would be the C2-epimer of isatindigobisindoloside $\mathrm{C}\left([\alpha]_{D}^{20}-33.9, c 0.11\right.$ in $\left.\mathrm{MeOH}\right)$ [35]. The experimental and calculated ECD curves of (2S)-23 matched well (Figure 3), which confirmed the $S$ absolute configuration of 23 [35,37], and the calculation details are listed in the Supporting Information (Figures S33 and S34). Acid hydrolysis of 23 resulted in the product of D-glucose, which was confirmed by GC analysis of the acetylation derivative of the hydrolysate of 23 and the authentic sugars $\left(t_{R} \mathrm{D}\right.$-glucose $45.23 \mathrm{~min}, t_{\mathrm{R}}$ L-glucose $\left.45.38 \mathrm{~min}\right)[8,9]$. The large coupling constant of Glc-H1 $(J=7.8 \mathrm{~Hz})$ revealed the $\beta$-glucopyranosyl linkage in 23 [38,39]. Accordingly, the structure of isatindigoside D (23) was elucidated as depicted (Figure 1). 
Table 2. ${ }^{1} \mathrm{H}-\mathrm{NMR}\left(600 \mathrm{MHz}\right.$ in DMSO- $\left.d_{6}\right)$ and ${ }^{13} \mathrm{C}-\mathrm{NMR}$ data (150 MHz in DMSO- $\left.d_{6}\right)$ of 23.

\begin{tabular}{|c|c|c|c|c|c|}
\hline \multirow{2}{*}{ No. } & \multicolumn{2}{|l|}{23} & \multirow{2}{*}{ No. } & \multicolumn{2}{|l|}{23} \\
\hline & $\delta_{\mathrm{H}}(J$ in $\mathrm{Hz})$ & $\delta_{\mathrm{C}}$ & & $\delta_{\mathrm{H}}(J$ in $\mathrm{Hz})$ & $\delta_{\mathrm{C}}$ \\
\hline $1 \mathrm{a}$ & 7.45, brs & & $3^{\prime \prime}$ & & 112.1 \\
\hline $1 b$ & 7.14, brs & 172.9 & $3 " \mathrm{a}$ & & 126.7 \\
\hline 2 & $5.68, \mathrm{~s}$ & 38.7 & $4^{\prime \prime}$ & $7.56, \mathrm{~d}(8.0)$ & 118.4 \\
\hline $1^{\prime}$ & $10.35, \mathrm{brs}$ & & $5^{\prime \prime}$ & 6.93, dd $(8.0,7.1)$ & 118.9 \\
\hline $2^{\prime}$ & & 126.8 & $6^{\prime \prime}$ & $7.04, \mathrm{dd}(8.1,7.1)$ & 120.5 \\
\hline $3^{\prime}$ & & 133.0 & $7^{\prime \prime}$ & $7.32, \mathrm{~d}(8.1)$ & 111.4 \\
\hline $3{ }^{\prime} \mathrm{a}$ & & 121.2 & 7"a & & 136.0 \\
\hline $4^{\prime}$ & $7.77, \mathrm{~d}(8.0)$ & 118.1 & Glc-1 & $4.63, \mathrm{~d}(7.8)$ & 106.6 \\
\hline $5^{\prime}$ & $6.92, \mathrm{dd}(8.0,7.2)$ & 118.4 & 2 & 3.38 , overlap & 74.1 \\
\hline $6^{\prime}$ & 6.97, dd $(8.1,7.2)$ & 120.8 & 3 & $3.26, \mathrm{~m}$ & 76.8 \\
\hline $7^{\prime}$ & $7.26, \mathrm{~d}(8.1)$ & 111.6 & 4 & $3.28, \mathrm{~m}$ & 69.8 \\
\hline $7^{\prime} \mathrm{a}$ & & 133.3 & 5 & $3.14, \mathrm{~m}$ & 77.2 \\
\hline $1^{\prime \prime}$ & 10.94, brs & & $6 a$ & $3.56, \mathrm{dd}(10.8,5.6)$ & \\
\hline $2^{\prime \prime}$ & $7.38, \mathrm{~s}$ & 123.9 & $6 b$ & 3.67 , dd $(10.8,1.8)$ & 61.0 \\
\hline
\end{tabular}

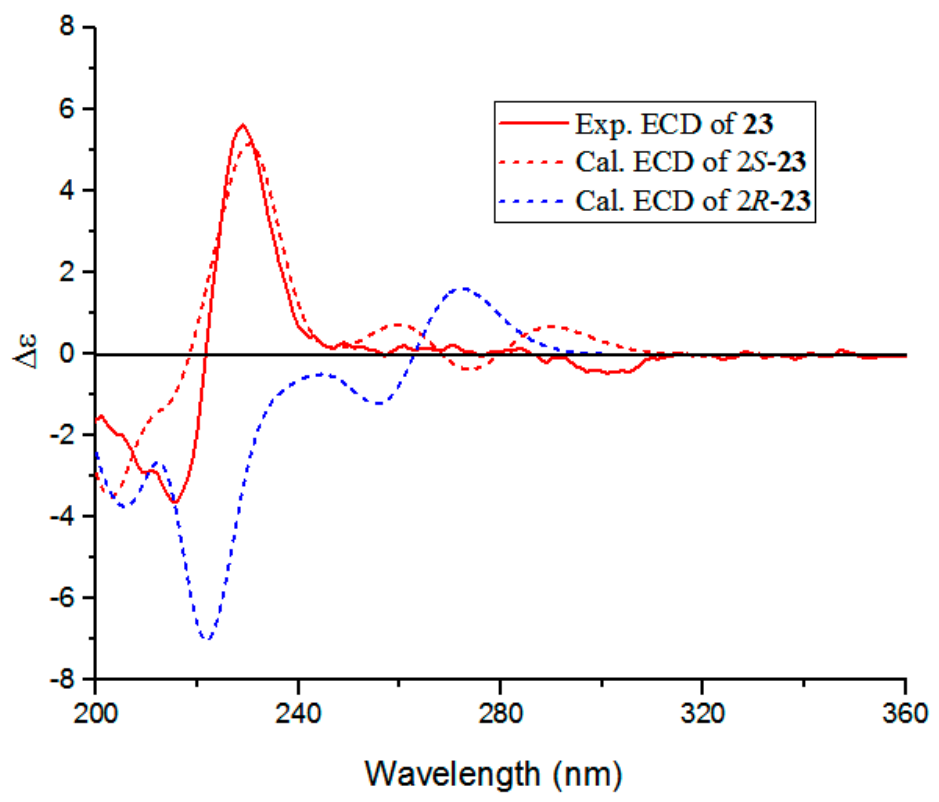

Figure 3. Experimental and calculated ECD spectra of 23.

NO is a messenger molecule that is widespread in cells and can affect a variety of physiological and pathological processes. The production of $\mathrm{NO}$ causes tissue damage and can trigger a variety of inflammatory diseases. LPS induces the release of NO from RAW264.7 cells by detecting the release of $\mathrm{NO}$ widely used to investigate the anti-inflammatory effects of the compounds $[2,10,40]$. As our ongoing phytochemical and pharmacological research project on I. tinctoria [8-12], Compounds 1-23 were obtained and were evaluated for their anti-inflammatory activity based on NO inhibitory effects in the LPS-activated RAW 264.7 cells [40]. The cytotoxicity of Compounds 1-23 were tested at three different concentrations $(25,50$, and $100 \mu \mathrm{M})$, and the results showed that only Compound 9 showed cytotoxicity above $25 \mu \mathrm{M}$, while the other compounds were above $100 \mu \mathrm{M}$. The results of NO production showed that Compounds 9, 15, and 17 exhibited inhibitory activities with $\mathrm{IC}_{50}$ values of 1.2, 5.0, and $74.4 \mu \mathrm{M}$ (Table 3). 
Table 3. NO inhibitory activities of Compounds 1-23 in RAW 264.7 cell line.

\begin{tabular}{cccccc}
\hline Compounds & $\mathbf{I C}_{\mathbf{5 0}}{ }^{\mathbf{a}}$ & Cytotoxicity & Compounds & IC $_{\mathbf{5 0}}{ }^{\mathbf{a}}$ & Cytotoxicity \\
\hline $\mathbf{1}$ & $>100$ & $>100$ & $\mathbf{1 3}$ & $>100$ & $>100$ \\
$\mathbf{2}$ & $>100$ & $>100$ & $\mathbf{1 4}$ & $>100$ & $>100$ \\
$\mathbf{3}$ & $>100$ & $>100$ & $\mathbf{1 5}$ & $5.0 \pm 1.3$ & $>100$ \\
$\mathbf{4}$ & $>100$ & $>100$ & $\mathbf{1 6}$ & $>100$ & $>100$ \\
$\mathbf{5}$ & $>100$ & $>100$ & $\mathbf{1 7}$ & $74.4 \pm 3.8$ & $>100$ \\
$\mathbf{6}$ & $>100$ & $>100$ & $\mathbf{1 8}$ & $>100$ & $>100$ \\
$\mathbf{7}$ & $>100$ & $>100$ & $\mathbf{1 9}$ & $>100$ & $>100$ \\
$\mathbf{8}$ & $>100$ & $>100$ & $\mathbf{2 0}$ & $>100$ & $>100$ \\
$\mathbf{9}$ & $1.2 \pm 0.9$ & $>25$ & $\mathbf{2 1}$ & $>100$ & $>100$ \\
$\mathbf{1 0}$ & $>100$ & $>100$ & $\mathbf{2 2}$ & $>100$ & $>100$ \\
$\mathbf{1 1}$ & $>100$ & $>100$ & $\mathbf{2 3}$ & $>100$ & $>100$ \\
$\mathbf{1 2}$ & $>100$ & $>100$ & $\mathrm{AG}^{\mathrm{b}}$ & $22.7 \pm 0.4$ & $>100$ \\
\hline
\end{tabular}

a $\mathrm{IC}_{50}$ values were expressed as mean $\pm \mathrm{SD}(n=3) .{ }^{\mathrm{b}} \mathrm{AG}=$ aminoguanidine hydrochloride was used as the positive control.

Isatisindigoticanine $\mathrm{G}(3)$ is the first example of a $8 \mathrm{H}$-pyrido[2,1-b]-11(9H)-quinazolinone moiety connected with a $1 \mathrm{H}$-indol-3-yl moiety via a $\mathrm{C}-\mathrm{C}$ bond of $\mathrm{C}-2$ "'-C-3'. For its unusual structural features, a plausible biosynthetic pathway is discussed in Figure 4. First, myrosinase catalyzed hydrolysis of progoitrin and epiprogoitrin to give 3a [1]. 3a was connected with 2-aminobenzoic acid moiety by steps of dehydration to give $\mathbf{3} \mathbf{b}$ [10], and then $\mathbf{3} \mathbf{c}$ was obtained via a cyclization reaction of $\mathbf{3} \mathbf{b}[2,11]$. $3 \mathbf{c}$ was connected with $1 \mathrm{H}$-indole moiety by enzyme-catalyzed reaction to give $\mathbf{3 d}$ [5] and was then changed via a dehydration reaction to give 3 [9-11].

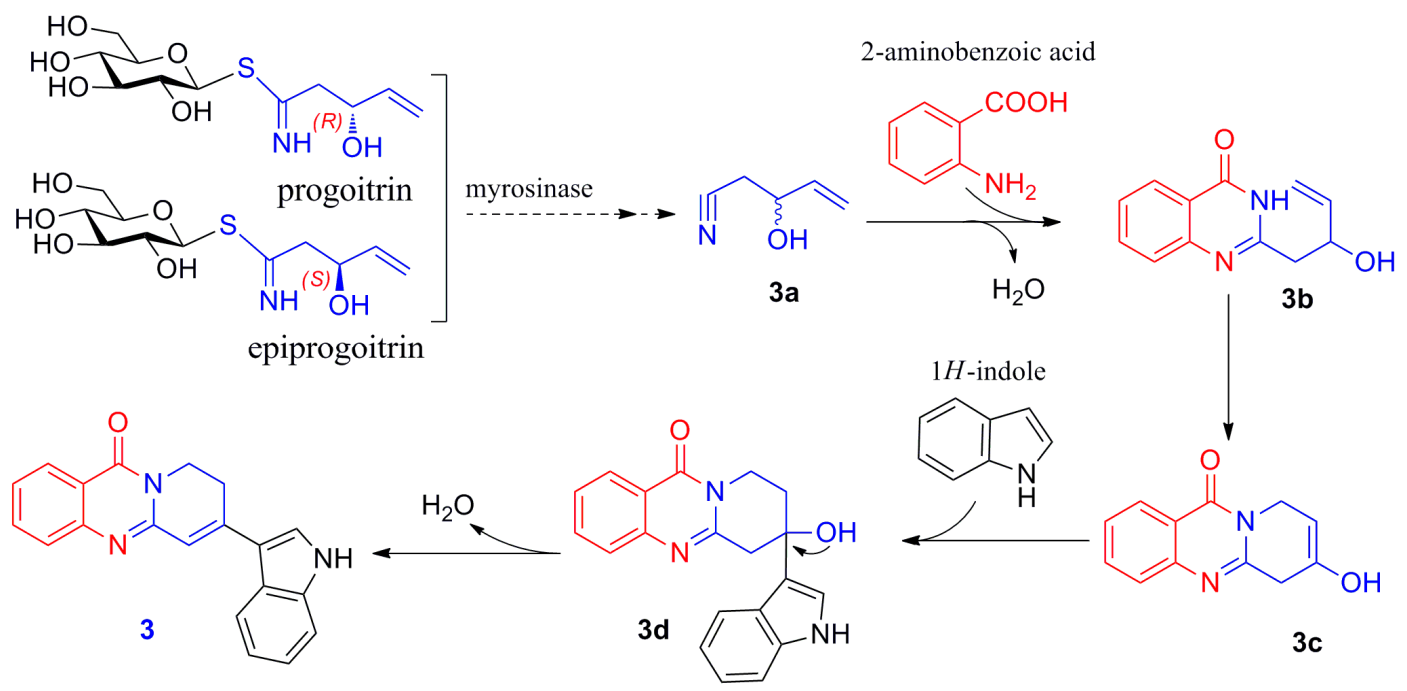

Figure 4. Putative biosynthetic pathway of 3.

\section{Experimental Section}

The General Experimental Procedures, Extraction and Isolation, Plant Materials, Inhibitory Assay of NO Production and ECD Calculation sections are listed in the Supporting Information.

\subsection{Physical and Spectroscopic Data of Isatisindigoticanines $E-G$ and Isatindigoside D}

Isatisindigoticanine $\mathrm{E}(\mathbf{1})$, a yellow amorphous powder; $\mathrm{IR}(\mathrm{KBr}) v_{\max }$ : 3406, 2923, 1647, 1609, 1556, $1517,1466,1383,1273,1093,745 \mathrm{~cm}^{-1} ; \mathrm{m} / \mathrm{z} 356.1398[\mathrm{M}+\mathrm{H}]^{+}\left(\right.$calculated $\left.356.1394[\mathrm{M}+\mathrm{H}]^{+}\right) ;{ }^{1} \mathrm{H}-\mathrm{NMR}$ (DMSO- $d_{6}, 600 \mathrm{MHz}$ ) and ${ }^{13} \mathrm{C}-\mathrm{NMR}$ (DMSO- $d_{6}, 150 \mathrm{MHz}$ ); see Table 1. 
Isatisindigoticanine $\mathrm{F}$ (2), a yellow amorphous powder; IR (KBr) $v_{\max }$ : 3456, 1679, 1621, 1516, 1461, 1319, 1206, 1135, 1021, 952, $749 \mathrm{~cm}^{-1} ; \mathrm{m} / \mathrm{z} 291.1125\left[\mathrm{M}-\mathrm{H}^{-}\right.$(calculated $291.1128[\mathrm{M}+\mathrm{H}]^{+}$); ${ }^{1} \mathrm{H}-\mathrm{NMR}$ (DMSO- $d_{6}, 600 \mathrm{MHz}$ ) and ${ }^{13} \mathrm{C}-\mathrm{NMR}\left(\mathrm{DMSO}-d_{6}, 150 \mathrm{MHz}\right.$ ); see Table 1.

Isatisindigoticanine $\mathrm{G}(3)$, a yellow amorphous powder; IR (KBr) $v_{\max }$ : 3404, 2919, 1708, 1601, 1468, $1400,1384,1092,745 \mathrm{~cm}^{-1} ; \mathrm{m} / z 314.1297\left[\mathrm{M}+\mathrm{H}^{+}\right.$(calculated $314.1288[\mathrm{M}+\mathrm{H}]^{+}$); ${ }^{1} \mathrm{H}-\mathrm{NMR}\left(\mathrm{DMSO}-d_{6}\right.$, $600 \mathrm{MHz}$ ) and ${ }^{13} \mathrm{C}-\mathrm{NMR}$ (DMSO- $d_{6}, 150 \mathrm{MHz}$ ); see Table 1.

Isatindigoside $\mathrm{D}(\mathbf{2 3})$, a red amorphous powder; $[\alpha]_{D}^{20}+12.1(c 0.19, \mathrm{MeOH}) ; \mathrm{IR}(\mathrm{KBr}) v_{\max }: 3420,2939$, 1722, 1598, 1514, 1461, 1261, 1069, 1025, 859, $813 \mathrm{~cm}^{-1}$; HRESIMS: $\mathrm{m} / z 490.1592[\mathrm{M}+\mathrm{Na}]^{+}$, (calculated $\left.490.1585[\mathrm{M}+\mathrm{Na}]^{+}\right) ;{ }^{1} \mathrm{H}$ and ${ }^{13} \mathrm{C}-\mathrm{NMR}\left(600\right.$ and $150 \mathrm{MHz}$ in DMSO- $\left.d_{6}\right)$; see Table 2.

\subsection{Absolute Configuration Determination of Sugar}

Compound $23(2 \mathrm{mg})$ was hydrolyzed in $2 \mathrm{M}$ hydrochloric acid $(4 \mathrm{~mL})$ at $80{ }^{\circ} \mathrm{C}$ for $2 \mathrm{~h}$. After cooling, the solution was concentrated under vacuum, dissolved with water, and extracted twice with dichloromethane $\left(\mathrm{CH}_{2} \mathrm{Cl}_{2}\right)$. The residue was dissolved in distilled water and reduced with $\mathrm{NaBH}_{4}$ for $3 \mathrm{~h}$ at room temperature. After neutralization with $\mathrm{AcOH}$ and evaporation to dryness, the residue was acetylated with $\mathrm{Ac}_{2} \mathrm{O}$ for $1 \mathrm{~h}$ at $100^{\circ} \mathrm{C}$. The resulting alditol acetate was subjected to GC analysis under the following conditions: capillary column, $\mathrm{HP}-5 \mathrm{~ms}(60 \mathrm{~m} \times 0.25 \mathrm{~mm} \times 0.25 \mu \mathrm{m})$; detector, FID; detector temperature, $280^{\circ} \mathrm{C}$; injection temperature, $280^{\circ} \mathrm{C}$; initial temperature $140{ }^{\circ} \mathrm{C}$, subsequently increased to $240{ }^{\circ} \mathrm{C}$ at a rate of $5^{\circ} \mathrm{C} / \mathrm{min}$, and then $1 \mathrm{~min}$ to increase to $260{ }^{\circ} \mathrm{C}$, finally, subsequent increase to $280^{\circ} \mathrm{C}$ at a rate of $2{ }^{\circ} \mathrm{C} / \mathrm{min}$; carrier, $\mathrm{N}_{2}$ gas [8,9]. The $\mathrm{D}$ glucose moiety in 23 was confirmed by the comparison of their retention times $\left(t_{R}\right)$ with those of authentic sugars $\left(t_{R}\right.$ D-glucose $45.23 \mathrm{~min}$, $t_{\mathrm{R}}$-glucose $\left.45.38 \mathrm{~min}\right)$.

\section{Conclusions}

In this paper, a total of 23 alkaloids were reported, including four new ones: isatisindigoticanines $E-G$ (1-3) and isatindigoside D (23). Four new natural products and 15 known analogues were isolated from Ban Lan Gen. Isatisindigoticanine $G$ possesses an unusual carbon skeleton of an $8 H$-pyrido[2,1-b]-11(9H)quinazolinone moiety connected with a $1 H$-indole moiety via a $\mathrm{C}-\mathrm{C}$ bond of $\mathrm{C}-2^{\prime \prime}-\mathrm{C}-3$ '. Compounds $\mathbf{9}$, 15 , and 17 showed NO inhibitory effects with $\mathrm{IC}_{50}$ values of $1.2,5.0$, and $74.4 \mu \mathrm{M}$ in the LPS-stimulated RAW264.7 macrophages. This study is important as it explains the chemical and biological diversity of Ban Lan Gen. Furthermore, the new structures need more biocativity experiments to discover their more meaningful uses, which may stimulate us to better develop and utilize these compounds.

Supplementary Materials: The following are available online http://www.mdpi.com/1420-3049/24/22/4033/s1, Copies of IR, HREIMS, ${ }^{1} \mathrm{H}-\mathrm{NMR},{ }^{13} \mathrm{C}-\mathrm{NMR}$, DEPT 135, HSQC, HMBC, and ${ }^{1} \mathrm{H}-{ }^{1} \mathrm{H}$ COSY of 1-3 and 23. Experimental and calculated ECD spectra of 23.

Author Contributions: R.W., Y.L., and K.C. conducted the experiments; D.R. and J.L. carried out the anti-inflammatory activity experiments; Y.S., Q.J., and W.Z. analyzed the MS, ECD, and NMR data; D.Z. did the isolation, confirmed the structures, and wrote the paper; R.W. oversaw the research project and drafted the paper.

Funding: This work was supported by the National Natural Science Foundation of China $(81573571,81673570)$, the Excellent Academic Leaders Program of Shanghai (16XD1403500), the programs of the High Level University Innovation Team, the Shanghai E-Research Institute of Bioactive Constituents in Traditional Chinese Medicine, and the Shanghai Scientific and Technological Innovation Program (18401931100).

Conflicts of Interest: No competing financial interests were declared by the authors.

\section{References}

1. Chen, M.H.; Lin, S.; Li, L.; Zhu, C.G.; Wang, X.L.; Wang, Y.A.; Jiang, B.Y.; Wang, S.J.; Li, Y.H.; Jiang, J.D.; et al. Enantiomers of an indole alkaloid containing unusual dihydrothiopyran and 1,2,4-thiadiazole rings from the root of Isatis indigotica. Org. Lett. 2015, 45, 1523-7052. [CrossRef] [PubMed] 
2. Yang, L.G.; Wang, G.; Wang, M.; Jiang, H.M.; Chen, L.X.; Zhao, F.; Qiu, F. Indole alkaloids from the roots of Isatis indigotica and their inhibitory effects on nitric oxide production. Fitoterapia 2014, 95, 175-181. [CrossRef] [PubMed]

3. Liu, S.F.; Zhang, Y.Y.; Zhou, L.; Lin, B.; Huang, X.X.; Wang, X.B.; Song, S.J. Alkaloids with neuroprotective effects from the leaves of Isatis indigotica collected in the Anhui Province, China. Phytochemistry 2018, 149, 132-139. [CrossRef] [PubMed]

4. Chen, M.H.; Gan, L.S.; Lin, S.; Wang, X.L.; Li, L.; Li, Y.H.; Zhu, C.G.; Wang, Y.A.; Jiang, B.Y.; Jiang, J.D.; et al. Alkaloids from the root of Isatis indigotica. J. Nat. Prod. 2012, 75, 1167-1176. [CrossRef] [PubMed]

5. Meng, L.J.; Guo, Q.L.; Chen, M.H.; Jiang, J.D.; Li, Y.H.; Shi, J.G. Isatindolignanoside A, a glucosidic indole-lignan conjugate from an aqueous extract of the Isatis indigotica roots. Chin. Chem. Lett. 2018, 29, 1257-1260. [CrossRef]

6. Meng, L.J.; Guo, Q.L.; Liu, Y.F.; Shi, J.G. 8,4'-Oxyneolignane glucosides from an aqueous extract of "ban lan gen" (Isatis indigotica root) and their absolute configurations. Acta Pharm. Sin. B 2017, 7, 638-646. [CrossRef]

7. Huang, Q.S.; Yoshihiro, K.; Natori, S. Isolation of 2-hydroxy-3-butenyl thiocyanate, epigoitrin and adenosine from “Banlangen" Isatis indigotica root. Planta Medica 1981, 42, 308-310.

8. Zhang, D.D.; Shi, Y.H.; Xu, R.; Du, K.; Guo, F.J.; Chen, K.X.; Li, Y.M.; Wang, R. Alkaloid Enantiomers from the Roots of Isatis indigotica. Molecules 2019, 24, 3140. [CrossRef]

9. Zhang, D.D.; Du, K.; Zhao, Y.T.; Shi, S.S.; Wu, Y.C.; Jia, Q.; Chen, K.X.; Li, Y.M.; Wang, R. Indole alkaloid glycosides from Isatis tinctoria roots. Nat. Prod. Res. 2019. [CrossRef]

10. Zhang, D.D.; Li, J.Y.; Ruan, D.Q.; Chen, Z.Q.; Zhu, W.L.; Shi, Y.H.; Chen, K.X.; Li, Y.M.; Wang, R. Lignans from Isatis indigotica roots and their inhibitory effects on nitric oxide production. Fitoterapia 2019, 137, 104189. [CrossRef]

11. Zhang, D.D.; Shi, Y.H.; Shi, S.S.; Wu, X.M.; Zhang, L.Q.; Chen, K.X.; Li, Y.M.; Wang, R. Isatisindigoticanine A, a novel indole alkaloid with an unpresented carbon skeleton from the roots of Isatis tinctoria. Nat. Prod. Res. 2019. [CrossRef] [PubMed]

12. Zhang, D.D.; Li, J.Y.; Shi, Y.H.; Chen, K.X.; Li, Y.M.; Wang, R. Glycosides from roots of Isatis indigotica. Chin. Tradit. Herb. Drugs 2019, 50, 3575-3580.

13. Shimokawa, Y.; Nakakoshi, M.; Saito, S.; Suzuki, H.; Yokoyama, Y.; Ishigami, A.; Nishioka, H.; Tsubuki, M. Synthesis and evaluation of 4 -aryl-2(1H)-quinolinones as potent amyloid $\beta$ fibrillogenesis inhibitors. Heterocycles 2012, 85, 1933-1940. [CrossRef]

14. Huang, Z.S.; Rao, Y.; Xu, Z.; Hu, Y.T.; Yu, H.; Gao, L. Preparation of Heterocycles as Antiobesity Agents. CN 107,721,982, 23 February 2018.

15. Javaid, K.; Saad, S.M.; Rasheed, S.; Moin, S.T.; Syed, N.; Fatima, I.; Salar, U.; Khan, K.M.; Perveen, S.; Choudhary, M.I. 2-Arylquinazolin-4(3H)-ones: A new class of $\alpha$-glucosidase inhibitors. Bioorg. Med. Chem. 2015, 23, 7417-7421. [CrossRef]

16. Hamasharif, M.S.; Smith, O.E.P.; Curran, C.J.; Hemming, K. N-alkylation and aminohydroxylation of 2-azidobenzenesulfonamide gives a pyrrolobenzothiadiazepine precursor whereas attempted $\mathrm{N}$-alkylation of 2-azidobenzamide gives benzotriazinones and quinazolinones. ACS Omega 2017, 3, 1222-1231. [CrossRef] [PubMed]

17. Kornsakulkarn, J.; Saepua, S.; Srijomthong, K.; Rachtawee, P.; Thongpanchang, C. Quinazolinone alkaloids from actinomycete Streptomyces sp. BCC 21795. Phytochem. Lett. 2015, 12, 6-8. [CrossRef]

18. Ruan, J.L.; Zou, J.H.; Cai, Y.L. Studies on chemical constituents in leaf of Isatis indigotica. China J. Chin. Mater. Med. 2005, 30, 1525-1526.

19. Yamaya, N.; Chau, N.; Iwakura, Y. Synthesis of quinazolinedione derivatives from 2-carbomethoxyphenyl isocyanate and amino acids. Seikei Daigaku Kogakubu Kogaku Hokoku 1982, 33, 2239-2240.

20. Goldfarb, D.S. Method Using Lifespan-Altering Compounds for Altering the Lifespan of Eukaryotic Organisms and Screening for Such Compounds. U.S. 20,090,163,545, 25 June 2008.

21. Suesse, M.; Cleve, D.; Johne, S. Process for the Preparation of 1,2,3,4-Tetrahydro-1-methyl-2,4-dioxo-3quinazolinealkanoates. DD 291,085, 20 June 1991.

22. Feng, Q.T.; Zhu, G.Y.; Gao, W.N.; Yang, Z.F.; Zhong, N.S.; Wang, J.R.; Jiang, Z.H. Two new alkaloids from the roots of Baphicacanthus cusia. Chem. Pharm. Bull. 2016, 64, 1505-1508. [CrossRef]

23. Mohn, T.; Plitzko, I.; Hamburger, M. A comprehensive metabolite profiling of Isatis tinctoria leaf extracts. Phytochemistry 2009, 70, 924-934. [CrossRef] 
24. Bandurco, V.T.; Wong, E.M.; Levine, S.D.; Hajos, Z.G. Antihypertensive pyrrolo[1,2-c]quinazolines and pyrrolo[1,2-c]quinazolinones. J. Med. Chem. 1981, 24, 1455-1460. [CrossRef] [PubMed]

25. Bingi, C.; Kola, K.Y.; Kale, A.; Nanubolu, J.B.; Atmakur, K. A simple one pot synthesis of novel tricyclic quinazolinones. Tetrahedron Lett. 2017, 58, 1071-1074. [CrossRef]

26. Ikuro, A.; Tsuyoshi, A.; Kiyofumi, W.; Hiroshi, N. Enzymatic formation of quinolone alkaloids by a plant type III polyketide synthase. Org. Lett. 2006, 8, 6063-6065.

27. Anilkumar, G.N.; Rosenblum, S.B.; Venkatraman, S.; Njoroge, F.G.; Kozlowski, J.A. 2,3-substituted Azaindole Derivatives for Treating Viral Infections. U.S. 8,404,845, 7 May 2010.

28. Li, Y.C.; Kuo, P.C.; Yang, M.L.; Chen, T.Y.; Hwang, T.L.; Chiang, C.C.; Thang, T.D.; Tuan, N.N.; Tzen, J.T.C. Chemical Constituents of the Leaves of Peltophorum pterocarpum and Their Bioactivity. Molecules 2019, 24, 240. [CrossRef]

29. Fuhr, U.; Strobl, G.; Manaut, F.; Anders, E.; Soergel, F.; Lopez-de-Binas, E.; Chu, D.T.W.; Pernet, A.G.; Mahr, G. Quinolone antibacterial agents: Relationship between structure and in vitro inhibition of the human cytochrome P450 isoform CYP1A2. Mol. Pharmacol. 1993, 43, 191-199.

30. Feng, C.; Shi, L.; Chen, D.Z.; Zhang, H.C.; Zhao, R.Q. Chemical constitutes of effective part in Celosia cristata for treatment of homostatic. Chin. Tradit. Herb. Drugs 2017, 48, 653-656.

31. Wang, D.; Wu, X.M.; Zhang, D.D.; Zhu, B.R.; Jia, Q.; Li, Y.M. Chemical constituents of carboxylic acid and its derivatives in Cinnamomi Ramulus. Chin. Tradit. Herb. Drugs 2019, 50, 8-12.

32. Cui, Y.W.; Yang, X.J.; Zhang, D.D.; Li, Y.Z.; Zhang, L.; Song, B.; Yue, Z.G.; Song, X.M.; Tang, H.F. Steroidal constituents from roots and rhizomes of Smilacina japonica. Molecules 2018, 23, 798. [CrossRef]

33. Li, Y.Z.; Wang, X.; He, H.; Zhang, D.D.; Jiang, Y.; Yang, X.J.; Wang, F.; Tang, Z.S.; Song, X.M.; Yue, Z.G. Steroidal saponins from the roots and rhizomes of Tupistra chinensis. Molecules 2015, 20, 13659-13669. [CrossRef]

34. Tashima, T.; Kodama, H.; Murata, H. Preparation of Hydroxamic Acid Derivatives as Histone Deacetylase (HDAC) Inhibitors. WO 2,014,196,328, 11 December 2014.

35. Liu, Y.F.; Chen, M.H.; Guo, Q.L.; Lin, S.; Xu, C.B.; Jiang, Y.P.; Li, Y.H.; Jiang, J.D.; Shi, J.G. Antiviral glycosidic bisindole alkaloids from the roots of Isatis indigotica. J. Asian. Nat. Prod. Res. 2015, 17, 689-704. [CrossRef]

36. Chen, Z.; Hu, G.Y.; Li, D.; Chen, J.; Li, Y.J.; Zhou, H.Y.; Xie, Y. Synthesis and vasodilator effects of rutaecarpine analogues which might be involved transient receptor potential vanilloid subfamily, member 1 (TRPV1). Bioorg. Med. Chem. 2009, 17, 2351-2359. [CrossRef] [PubMed]

37. Chen, X.Y.; Zhang, T.; Wang, X.; Hamann, M.T.; Kang, J.; Yu, D.Q.; Chen, R.Y. A chemical investigation of the leaves of Morus alba L. Molecules 2018, 23, 1018. [CrossRef] [PubMed]

38. Song, X.M.; Zhang, D.D.; He, H.; Li, Y.Z.; Yang, X.J.; Deng, C.; Tang, Z.S.; Cui, J.C.; Yue, Z.G. Steroidal glycosides from Reineckia carnea. Fitoterapia 2015, 105, 240-245. [CrossRef] [PubMed]

39. Zhang, D.D.; Wang, W.; Li, Y.Z.; Li, Z.; Jiang, Y.; Tang, Z.S.; Song, X.M.; Yue, Z.G. Two new pregnane glycosides from Reineckia carnea. Phytochem. Lett. 2016, 15, 142-146. [CrossRef]

40. Han, M.F.; Zhang, X.; Zhang, L.Q.; Li, Y.M. Iridoid and phenylethanol glycosides from Scrophularia umbrosa with inhibitory activity on nitric oxide production. Phytochem. Lett. 2018, 28, 37-41. [CrossRef]

Sample Availability: Samples of the Compounds 1-23 are available from the authors.

(C) 2019 by the authors. Licensee MDPI, Basel, Switzerland. This article is an open access article distributed under the terms and conditions of the Creative Commons Attribution (CC BY) license (http://creativecommons.org/licenses/by/4.0/). 